\title{
KAJIAN DESKRIPTIF STRUKTURAL WACANA GRAFITI PADA TRUK
}

\author{
Oleh : \\ Siti Junawaroh \\ Fakultas Ilmu Budaya Universitas Diponegoro
}

\begin{abstract}
This paper is entitled "A Descriptive Study of Graffiti Discourse Structure on Trucks". This research discusses about language unity form on the trucks.The purpose of this research is to describe writing language unity on the truck which consists of words, phrases, clauses and sentences of writing on the trucks.

The method used in this research was qualititative descriptive and the techniques used was observationtechnique. Here, the writer usedrecorded and written techniqueduring this research. In analyzing data, the writer usessubtitution method..

According to the analysis on the data, the writing on the truk is decrypted according to language unity in the form of words, phrases, clauses, and sentences. The words found are in the form of nouns, verbs, and adjectives. The phrases found arein the form of nominal subordinative phrases, nominal coordinative phrases, verb subordinative phrases, and adjectival subordinative phrases. The clauses found includes $S-P, P-S$, and $S$ - $P$-The sentences which are found are declarative sentencesand affirmative sentences.
\end{abstract}

Key words:

\section{PENDAHULUAN}

Wacana grafiti adalah bentuk wacana tulisan dalam media tertentu sebagai bentuk ekspresi si pembuat tulisan. Grafiti juga dimaknai sebagai kegiatan dari seni rupa yang menggunakan komposisi warna, garis, bentuk dari volume untuk menuliskan kalimat tertentu di atas dinding (Wicandra \& Angkadjaja, 2005). Wacana grafiti biasanya menggunakan media yang tidak lazim dipakai untuk menulis, misalnya pada tembok, tubuh manusia, atau kendaraan.

Tulisan ini merupakan kajian permulaan dari kajian linguistik dengan objek grafiti pada truk. Untuk melihat terbentuknya struktur wacana grafiti pada truk, perlu dilakukan kajian deskriptif-struktural secara komprehensif.

\section{METODE}

Data yang diambil dari informan diperoleh dengan menggunakan metode simak (observasi) (Sudaryanto, 1988:2).Metode simak dilakukan dengan teknik catat. Untuk analisis data, penulis menggunakan metode agih. Metode agih adalah metode yang alat penentunya merupakan bagian dari bahasa yang diteliti (Sudaryanto dalam Kesuma, 2007: 54).Teknik dalam metode agih yang digunakan adalah teknik bagi unsur langsung dan teknik sisip. Teknik bagi unsur langsung digunakan untuk memilah satuan gramatika dari yang terkecil sampai terbesar yang dapat dianalisis (kata, frase, klausa, kalimat, dan wacana). Teknik sisip adalah teknik analisis data dengan cara menyisipkan satuan kebahasaan lain di antara konstruksi yang dianalisis. Penerapan teknik inidilakukan untuk mengetahui satuan gramatika tersebut 
berupa kata majemuk ataukah frase, klausa ataukah kalimat, dan kalimat majemuk setara ataukah bertingkat.

\section{III.PEMBAHASAN}

Untuk mendapatkan gambaran yang komprehensif tentang struktur wacana grafiti, maka beberapa aspek wacana dianalisis lebih detil.Analisis sistem gramatika yang terdapat dalam tulisan grafiti pada kendaraan truk dapat dipilah menjadi komponen kata, frase, klausa, dan kalimat. Dalam arti bahwa wacana tulisan grafiti pada kendaraan truk ada yang berkategori kata, frase, klausa, dan kalimat.

\section{Kata}

a. Adjektiva

1) Sportif

Sportif merupakan kata serapan dari bahasa Inggris yang berkategori adjektiva. Sportif mempunyai makna (1) bersifat kesatria, jujur dan sebagainya; (2) tegap, gagah (KBBI, 2008:1336). Sportif merupakan sebuah kata yang terdiri atas tujuh fonem, yaitu $/ \mathrm{s} /, / \mathrm{p} /, / \mathrm{o} /, / \mathrm{r} /, / \mathrm{t} /, / \mathrm{i} /$, dan /f/. Kata sportif termasuk ke dalam kata adjektiva. Sportif tidak dapat didampingi oleh adverbia frekuensi sering, jarang, dan kadang-kadang menjadi *sering sportif, *jarang sportif, dan *kadang-kadang sportif. Sportif tidak dapat didampingi oleh adverbia jumlah menjadi *sebuah sportif.Sportif dapat didampingi oleh semua adverbia derajat agak (lebih, sangat, paling) menjadi lebih sportif, sangat sportif, dan paling sportif. Sportif dapat didampingi oleh adverbia kepastian pasti, tentu, mungkin, barangkali menjadi pasti sportif, tentu sportif, mungkin sportif, dan barangkali sportif. Sportif tidak dapat diberi adverbia kala (tenses) hendak dan mau menjadi *hendak sportif dan *mau sportif.

\section{2) Prihatin}

Kata prihatin merupakan kata dasar yang bermakna bersedih hati, was-was, bimbang (karena usahanya gagal, mendapat kesulitan, mengingat akan nasibnya dan sebagainya; menahan diri, bertarak (KBBI, 2008:1102). Prihatin merupakan sebuah kata yang terdiri atas delapan fonem, yaitu / $p, r, I, h, a, t, I, n /$. Kata prihatin termasuk ke dalam kata adjektiva. Kata prihatin tidak dapat didampingi oleh adverbia jumlah menjadi *sebuah prihatin.Prihatin dapat didampingi oleh semua adverbia derajat agak (lebih, sangat, paling) menjadi lebih prihatin, sangat prihatin, dan paling prihatin. Prihatin dapat didampingi oleh adverbia kepastian pasti, tentu, mungkin, barangkali menjadi pasti prihatin, tentu prihatin, mungkin prihatin, dan barangkali prihatin.

\section{b. Nomina}

1) Pemburu

Pemburu merupakankata dasar dan terdiri dari tujuh fonem, yaitu Ip,e,m,b,u,r,u/. Pemburu merupakan bentuk nomina. Hal ini dapat dibuktikan bahwa pemburu tidak dapat didahului oleh adverbia negasi tidak menjadi *tidak pemburu. Pemburu tidak dapat didahului oleh adverbia derajat agak (lebih, sangat, dan paling) menjadi *lebih pemburu, * sangat pemburu, dan *paling pemburu. Pemburu tidak dapat didahului oleh adverbia keharusan wajib menjadi *wajib pemburu.Pemburu dapat didahului oleh adverbia yang menyatakan jumlah menjadi seorang pemburu.Pemburu bermakna orang yang kerjanya berburu binatang; alat (perkakas, perlengkapan dan sebagainya) untuk berburu (mengejar dan sebagainya) (KBBI, 2008: 227).

\section{c. Verba}

\section{1) Terkendali}

Terkendali merupakan sebuah kata berimbuhan dari kata dasar kendali yang bermakna kekang (KBBI, 2008:668). Kata tersebut mengalami proses morfologi afiksasi ter- menjadi terkendali yang bermakna telah (dapat) dikendalikan (KBBI, 2008: 668). Terkendali terdiri dari sepuluh fonem, yaitu /t,e,r,k,e,n,d,a,l,i/. Terkendali termasuk ke dalam bentuk 
verba. Terkendali dapat didampingi oleh adverbia negasi tidak dan tanpa menjadi tidak terkendali dan tanpa terkendali. Terkendali dapat didampingi oleh semua adverbia frekuensi menjadi sering terkendali, jarang terkendali, dan kadangkadang terkendali. Terkendali tidak dapat didampingi oleh kata bilangan dengan penggolongannya menjadi *sebuah terkendali. Namun, dapat didampingi oleh semua adverbia jumlah menjadi sedikit terkendali. Terkendali tidak dapat didampingi oleh semua adverbia derajat menjadi *lebih terkendali, *sangat terkendali, dan *paling terkendali. Terkendali dapat didampingi oleh semua adverbia kala menjadi hendak terkendali dan mau terkendali. Terkendali dapat didampingi oleh semua adverbia keselesaian menjadi sudah terkendali. Terkendali dapat didampingi oleh semua adverbia keharusan menjadi boleh terkendali, harus terkendali, dan wajib terkendali. Terkendali dapat didampingi oleh semua anggota adverbia kepastian menjadi pasti terkendali, tentu terkendali, mungkin terkendali, dan barangkali terkendali.

\section{Frase}

Dari penelitian yang dilakukan terdapat frase nominal subordinatif (FNS), frase nominal koordinatif (FNK), frase verbal subordinatif (FVS), dan frase adjektival subordinatif (FAS).

a. Frase Nominal Subordiatif (FNS)

1) dewa ruci

Frase dewa ruci terdiri atas dua kata yakni dewa $(\mathrm{N})$ dan ruci $(\mathrm{N})$. Struktur dewaruci termasuk struktur frase karena struktur tersebut tidak melebihi batas fungsi sebuah frase dan bersifat nonpredikatif karena unsur dewa dan ruci yang membentuk frase tidak berstruktur subjek-predikat atau predikat-objek. dewa merupakan unsur pusat (Up), yaitu unsur yang secara distribusional sama dengan seluruh frase dan secara semantik merupakan unsur yang terpenting, sedangkan ruci merupakan atributif. Unsur pusat yaitu kata dewa dimodifikasi dengan unsur atributif yaitu ruci.

\section{2) putra minang}

Frase putra minang terdiri atas dua kata yakni putra $(\mathrm{N})$ dan minang $(\mathrm{N})$. Struktur putra minang termasuk struktur frase karena struktur tersebut tidak melebihi batas fungsi sebuah frase dan bersifat nonpredikatif karena unsur putra dan minang yang membentuk frase tidak berstruktur subjek-predikat atau predikatobjek. putra merupakan unsur pusat (Up), yaitu unsur yang secara distribusional sama dengan seluruh frase dan secara semantik merupakan unsur yang terpenting, sedangkan minang merupakan atributif. Unsur pusat yaitu kata putra dimodifikasi dengan unsur atributif yaitu minang.

\section{3) gilang jaya}

Frase gilang jaya terdiri atas dua kata yakni gilang $(\mathrm{N})$ dan jaya (A). Struktur gilang jaya termasuk struktur frase karena struktur tersebut tidak melebihi batas fungsi sebuah frase dan bersifat nonpredikatif karena unsur gilang dan jaya yang membentuk frase tidak berstruktur subjek-predikat atau predikat-objek. gilang merupakan unsur pusat (Up), yaitu unsur yang secara distribusional sama dengan seluruh frase dan secara semantik merupakan unsur yang terpenting, sedangkan jaya merupakan atributif. Unsur pusat yaitu kata gilang dimodifikasi dengan unsur atributif yaitu jaya.

4) jagat satria

Frase jagat satria terdiri atas dua kata yakni jagat (N) dan satria (A). Struktur jagat satria termasuk struktur frase karena struktur tersebut tidak melebihi batas fungsi sebuah frase dan bersifat nonpredikatif karena unsur jagat dan satria yang membentuk frase tidak berstruktur subjek-predikat atau predikatobjek. jagat merupakan unsur pusat (Up), yaitu unsur yang secara distribusional sama dengan seluruh frase dan secara semantik merupakan unsur yang terpenting, sedangkan satria merupakan atributif. 
Unsur pusat yaitu kata jagat dimodifikasi dengan unsur atributif yaitu satria.

\section{5) anak lanang}

Frase anak lanang terdiri atas dua kata yakni anak 'anak'(N) dan lanang 'laki-laki'(N). Struktur teguhputra termasuk struktur frase karena struktur tersebut tidak melebihi batas fungsi sebuah frase dan bersifat nonpredikatif karena unsur anak dan lanang yang membentuk frase tidak berstruktur subjek-predikat atau predikat-objek. anak merupakan unsur pusat (Up), yaitu unsur yang secara distribusional sama dengan seluruh frase dan secara semantik merupakan unsur yang terpenting, sedangkan lanang merupakan atributif. Unsur pusat yaitu kata anak dimodifikasi dengan unsur atributif yaitu lanang. Frase anak lanang dibatasi maknanya oleh kata lanang yang berasal dari bahasa Jawa yang bermakna 'lakilaki'sehingga maknanya menjadi anak lakilaki.

\section{b. Frase Nominal Koordinatif (FNK) \\ 1) romeo juliet}

Frase romeo juliet merupakan satuan gramatikal yang berupa gabungan kata yang bersifat nonpredikatif karena unsur romeo dan juliet yang membentuk frase tidak berstruktur subjek-predikat atau predikat-objek. romeo dan juliet merupakan morfem bebas karena tanpa kehadiran morfem lain dapat muncul dalam pertuturan. Romeo juliet termasuk ke dalam frase nominal koordinatif karena salah satu komponennya setara dan tidak dapat saling menggantikan. Frase romeo juliet tersebut mempunyai komponen pembentuk yang terdiri atas dua unsur yang setara atau terdiri dari dua komponen yang sama dan sederajat, dan secara potensial dapat dihubungkan oleh konjungsi koordinatif atau. Misalnya, dalam kalimat romeo atau juliet akan pergi.

\section{c. Frase Verbal Subordiatif (FVS) cave deh}

Frase cave deh berasal dari frase capai deh, yang terdiri atas dua kata yakni capai (A) dan deh (Atr). Struktur capai dehk termasuk struktur frase karena struktur tersebut tidak melebihi batas fungsi sebuah frase dan bersifat nonpredikatif karena unsur capai dan deh yang membentuk frase tidak berstruktur subjek-predikat atau predikat-objek. capai merupakan unsur pusat (Up), yaitu unsur yang secara distribusional sama dengan seluruh frase dan secara semantik merupakan unsur yang terpenting, sedangkan deh merupakan atributif. Unsur pusat yaitu kata capai dimodifikasi dengan unsur atributif yaitu deh.

\section{d. Frase adjektival Subordiatif (FAS) pernah muda}

Frase pernah muda terdiri atas dua kata yakni pernah (Atr) dan muda (A). Struktur pernah muda termasuk struktur frase karena struktur tersebut tidak melebihi batas fungsi sebuah frase dan bersifat nonpredikatif karena unsur pernah dan muda yang membentuk frase tidak berstruktur subjek-predikat atau predikatobjek. muda merupakan unsur pusat (Up), yaitu unsur yang secara distribusional sama dengan seluruh frase dan secara semantik merupakan unsur yang terpenting, sedangkan pernah merupakan atributif. Unsur pusat yaitu kata muda dimodifikasi dengan unsur atributif yaitu pernah. Frase pernah muda dibatasi maknanya oleh kata pernah sehingga maknanya menjadi 'pernah merasakan masa muda'. 


\section{Klausa}

Pemakaian klausa wacana grafiti pada truk berpola S-P, P-S, dan S-P-Pel.

a. Klausa berpola S-P

1) aku tak berdaya

Klausa aku tak berdaya merupakan klausa terdiri atas tiga kata yaitu $a k u, t a k$, tak, dan berdaya. Konstruksi aku tak berdaya merupakan klausa lengkap dan belum merupakan kalimat karena tidak disertai dengan intonasi final. Berdasarkan fungsinya, $a k u$ berfungsi sebagai $\mathrm{S}$ dan tak berdaya berfungsi sebagai P.

2) doamu harapanku

Klausa doamu harapanku merupakan klausa yang terdiri atas dua kata yaitu doamu dan harapanku. Konstruksi doamu harapanku merupakan klausa lengkap dan belum merupakan kalimat karena tidak disertai dengan intonasi final. Berdasarkan fungsinya, doamu berfungsi sebagai S, dan harapanku berfungsi sebagai $\mathrm{P}$.

\section{b. Klausa berpola P-S}

esih penak zamanku

Klausa esih penak zamanku merupakan klausa yang berasal dari bahasa Jawa. Konstruksi ini terdiri atas tiga kata yaitu esih, penak, dan zamanku. Sebagai satuan fonologik, kata esih terdiri dari dua suku yaitu $e$ dan sih dan terdiri dariempat fonem / e,s,i,h/, penak terdiri dari dua suku yaitu pe dan nak dan terdiri atas lima fonem /p,e,n,a,k/, dan zamanku terdiri dari tiga suku yaitu $z a, m a n$, dan $k u$ dan terdiri atas tujuh fonem /z,a,m,a,n,k,u/. Konstruksi Esih penak zamanku merupakan klausa lengkap dan belum merupakan kalimat karena tidak disertai dengan intonasi final. Berdasarkan fungsinya, esih penak berfungsi sebagai $\mathrm{P}$, dan zamanku berfungsi sebagai S.

c. Klausa berpola S-P-Pel

beratnya rindumu tak seberat muatanku

Klausa beratnya rindumu tak seberat muatanku merupakan klausa terdiri atas lima kata yaitu beratnya, rindumu, tak, seberat, dan muatanku. Konstruksi beratnya rindumu tak seberat muatanku merupakan klausa lengkap dan belum merupakan kalimat karena tidak disertai dengan intonasi final. Berdasarkan fungsinya, beratnya rindumu berfungsi sebagai S, tak seberat berfungsi sebagai $\mathrm{P}$, dan muatanku berfungsi sebagai Pel.

\section{Kalimat}

a. Kalimat berita

1) Dua anak cukup dua istri bangkrut.

Kalimat dua anak cukup dua istri bangkrut terdiri atas dua klausa, yakni klausa dua anak cukup (1) dan klausa dua istri bangkrut (2). Berdasarkan fungsi, klausa (1) terdiri atas dua anak (S) dan cukup (P). Klausa (2) dua istri berfungsi sebagai $\mathrm{S}$ dan bangkrut sebagai P.

2) Gara-gara sms bojoku minggat.

Kalimat gara-gara sms bojoku minggat merupakan kalimat tunggal karena terdiri atas satu klausa. Berdasarkan fungsi, gara-gara sms berfungsi sebagai ket, bojoku sebagai $\mathrm{S}$, dan minggat sebagai $\mathrm{P}$.

3) Benteng yang paling kuat adalah wanita solehah.

Kalimat benteng yang paling kuat adalah wanita solehah merupakan kalimat tunggal karena terdiri atas satu klausa. Berdasarkan fungsi, benteng yang paling kuat berfungsi sebagai $\mathrm{S}$, adalah sebagai $\mathrm{P}$, dan wanita solehah sebagai pel.

4) Asal abang kuat nanjak, lewat aje.

Kalimat asal abang kuat nanjak, lewat aje merupakan kalimat majemuk bertingkat karena terdiri atas dua klausa, yakni klausa utama Ø lewat aje dan klausa bawahan asal abang kuat nanjak. Berdasarkan fungsi pada klausa utama terdapat $\mathrm{S}$ yang dilesapkan yakni abang, lewat aje berfungsi sebagai P. Pada klausa bawahan abang sebagai $\mathrm{S}$, kuat berfungsi sebagai $\mathrm{P}$, nanjak sebagai pel, dan konjungsi asal. 
5) Cinta bersemi saat dompetku berisi. Kalimat cinta bersemi saat dompetku berisi merupakan kalimat majemuk bertingkat karena terdiri atas dua klausa, yakni klausa utama cinta bersemi dan klausa bawahan saat dompetku berisi. Berdasarkan fungsi pada klausa utama terdapat $\mathrm{S}$ cinta, bersemi berfungsi sebagai P. Pada klausa bawahan dompetku sebagai $\mathrm{S}$, berisi berfungsi sebagai $\mathrm{P}$, dan konjungsi saat.

6) Si miskin merana cari makan tambah sulit.

Kalimat si miskin merana cari makan tambah sulit merupakan kalimat majemuk setara karena terdiri atas dua klausa yang berkedudukan setara, yakni klausa pertama si miskin merana dan klausa kedua cari makan tambah sulit. Berdasarkan fungsi pada klausa pertama terdapat $\mathrm{S}$ yang si miskin, merana berfungsi sebagai $\mathrm{P}$. Pada klausa kedua si miskin sebagai S, cari makan berfungsi sebagai $\mathrm{P}$, tambah sulit sebagai pel.

7) Putus cinta soal biasa, putus rem mati kita.

Kalimat putus cinta soal biasa, putus rem mati kita merupakan kalimat majemuk setara karena terdiri atas dua klausa yang berkedudukan setara, yakni klausa pertama putus cinta soal biasa dan klausa kedua putus rem mati kita. Berdasarkan fungsi pada klausa pertama terdapat $\mathrm{S}$ yang putus cinta, soal biasa berfungsi sebagai P. Pada klausa kedua putus rem sebagai $\mathrm{S}$, mati berfungsi sebagai $\mathrm{P}$, kita sebagai pel. b. Kalimat Perintah

Kalimat perintah berhubungan dengan situasi. Kalimat suruh mengharapkan tanggapan yang berupa tindakan dari orang yang diajak berbicara.

Wedi karo bojo, kawin maning bae.

Kalimat wedi karo bojo, kawin maning bae merupakan kalimat majemuk bertingkat karena terdiri atas dua klausa, yakni klausa utama kawin maning bae dan klausa bawahan wedi karo bojo. Berdasarkan fungsi pada klausa utama terdapat $\mathrm{S} \emptyset$, kawin maning bae berfungsi sebagai P. Pada klausa bawahan $\varnothing$ sebagai $\mathrm{S}$, wedi berfungsi sebagai $\mathrm{P}$, dan karo bojo berfungsi sebagai ket.

\section{PENUTUP}

Struktur gramatika yang terdapat dalam wacana grafiti meliputi pemakaian kata, frase, klausa, dan kalimat. Pemakaian kata meliputi adjektiva, nomina, dan verba. Pemakaian frase meliputi frase nominal subordinatif, frase nominal koordinatif, frase verbal subordinatif, dan frase adjektival subordinatif. Pemakaian klausa meliputi klausa berpola S-P, P-S, dan S-PPel. Pemakaian kalimat meliputi kalimat berita dan kalimat suruh 


\section{DAFTAR PUSTAKA}

Chaer, Abdul. 1995. Pengantar Semantik Bahasa Indonesia. Jakarta: PT Rineka Cipta.

Chaer, Abdul. 2003. Linguistik Umum. Jakarta: Rineka Cipta.

Chaer, Abdul. 2007. Linguistik Umum. Jakarta: Rineka Cipta.

Chaer, Abdul. 2008. Morfologi bahasa Indonesia (Pendekatan proses). Jakarta: PT Rineka Cipta.

Kridalaksana, Harimurti. 1983. Kamus Linguistik. Jakarta: PT Gramedia.

Kridalaksana, Harimurti. 2007. Pembentukan Kata dalam Bahasa Indonesia. Jakarta: Gramedia Pustaka Utama.

Kesuma, Jati Mastoyo Tri. 2007. Pengantar (Metode) Penelitian Bahasa.Yogyakarta: Carasvatibooks.

Mahsun. 2005. Metode Penelitian Bahasa. Jakarta: PT Raja Grafindo Persada.
Parera, J.D. 2009. Dasar-Dasar Analisis Sintaksis. Jakarta: Penerbit Erlangga.

Pudjosoedarmo, soepomo, dkk. 1979. Morfologi Bahasa Jawa. Jakarta: Pusat Pembinaan dan Pengembangan Bahasa.

Pusat Bahasa Departemen Pendidikan Nasional. 2006. Kamus Besar Bahasa Indonesia. Surabaya: Kashiko.

Ramlan. 1997. Morfologi. Yogyakarta: C.V. Karyono.

Ramlan, M. 2001. Sintaksis.Yogyakarta: C.V. Karyono.

Sudaryanto. 1993. Metode dan Aneka Teknik Analisis Bahasa. Yogyakarta: Duta Wacana University Press.

Tarigan, Henry Guntur. 1984. Pengajaran Sintaksis. Bandung: Angkasa.

Wicandra dan Angkadjaja.2005. "Efek Ekologi Visual dan Sosiokultural Melalui Grafiti Artistik di Surabaya". Nirmala. Vol 7 No 2. 